\title{
DAMAGE TO RAILWAY BRIDGING
}

\author{
*J. B. Wilson
}

The distance between Reefton and Westport on the Stillwater-Westport railway is 46 miles, and there are fifty railway bridges of various types with ages ranging from recently completed to sixty years old.

Initial reconnaissance following the 'quake showed that all spans had remained on the piers, although on several bridges some of the piers were seriously weakened. Nevertheless most of the bridges, particularly if situated at more than four miles from Inangahua railway station, suffered little if any damage.

For convenience, bridging damage may be described by type as follows:

(a) Twentynine smaller bridges have simple timber or steel spans on Australian hardwood timber piled piers - a typical bridge comprises $5 / 20^{\prime}$ spans at $12^{\prime}$ height above ground level. Damage generally was slight, apart from approach fill settlements.

(b) Of three, sixty years old combined rail and road bridges, each of which averages about six 70' long timber truss spans, two were on timber piled piers and were undamaged, but damage to the "Landing" bridge on $40 \mathrm{ft}$ high mass concrete piers and $25 \mathrm{ft}$ high mass concrete abutments threatened to be the key factor in the re-opening of the entire railway. One abutment wing wall had moved outwards a foot and, in the process had permitted the shattering of the supporting concrete for one end of a timber truss span. Collapse of massive marginclly stable fractured mass concrete could have progressively pulled down the entire bridge because the mass concrete piers were also cracked through near their tops. Abutment underpinning was in fact successful.

(c) Of twelve generally modern bridges of type having steel spans on reinforced concrete foundations, ten were virtually undamaged. Two however, the combined rail and road bridge over the Inangahua river one mile north, and the Buller railway bridge two miles north of Inangahua railway station, over the Inangahua and Buller rivers respectively, suffered serious cracking and displacements to piers and abutments. The Buller bridge comprises six 100 feet noncontinuous through plate girder spans on $50 \mathrm{ft}$ high twin reinforced concrete cylinder piers. Span to pier connections proved adequate to prevent spans from falling off, and damage was mainly restricted to cracking of piers and abutments due to longitudinal (along track) span displacements of up to one foot. Piers of the Inangahua combined road and rail bridge (of construction comparable with Buller) were even more severely damaged due to displacements (resulting from the 1929 Murchison and 1968 Inangahua earthquakes) which measured up to about one foot both laterally and longitudinally. A number of the Inangahua bridge piers may have to be rebuilt. 
On the road half of this bridge the original timber roadway deck had been replaced with a concrete slab thus adding to the dead weight, and near water level at underside of the reinforced concrete diaphragm between twin concrete cylinder pier foundations the cylinder reinforcing hooping steel was at over 4 feet centres vertically and slabbing of concrete accompanied cracking and fracture of longitudinal reinforcing rods.

(d) The six all concrete bridges are generally of modern design. Typical span lengths are $40 \mathrm{ft}$ and piers range up to sixty feet high. No discermible damage occurred to these bridges except for the small road overbridge across the railway about one mile north from the Inangahua railway station, which bridge suffered significant distortion. The nearest to Inangahua railway station of the other concrete rail bridges is in the Buller Gorge some eleven miles away.

Mr J. P. Hollings, Consulting Engineer, Wellington, has carried out detailed measurements of the damage to these bridges and will be submitting a technical paper (See Bulletin Vol. 1 No. 2). 